\title{
THE COMMERCE COURT-ITS ORIGIN, ITS POWERS AND ITS JUDGES
}

\author{
By J. Newton Baker, LL.M., J. D., of the Pennsylvania Bar.
}

President Taft, on January 7,1910 , in his special message to Congress, presented an outline of a bill drafted by the AttorneyGeneral of the United States designated to establish and create a central court, to be located in Washington, District of Columbia, which many legislators and Department officials considered suitable for an amendment to the Interstate Commerce Act.

This court of the United States, to be known as the Commerce Court, was proposed and designated to prevent delay incident to the adjudication and prosecution of cases under the Act to Regulate Commerce in the various United States courts; to overcome the apparent inability of the Federal Judges to adequately meet the technical and conflicting evidence submitted, and the dissimilarity and contrariety of opinions issuing from different Federal Courts. Uniformity of decisions in matters of interstate transportation is not only necessary but advantageous, and the expeditious adjudication of important questions of gigantic proportions now delayed will be gratefully received by traffic and the commercial world.

The recommendation met severe rebuff and sharp criticism in Congress. This arrogant method of procedure before this court was niodified by the "insurgent" element upon the floor of the Senate, which action plainly clemonstrated the power and will of the people who are determined to defend their rights for equality and justice in transportation affairs. Finally the bill was adopted, although its necessity was doubted, it being regarded as an unnecessary judiciary and an expenditure of no vital importance or significance, inasmuch as Congress in recent years had created and established a sufficiency of inferior courts, and that the United States Supreme Court curtailed the power of the courts over the orders of the Interstate Commerce Commission giving that Commission greater scope and authority over matters it clecided after investigation. Therefore, unless its jurisdiction is extended, it is evident that the docket of the Commerce Court, after the accumulated suits are decided, will never be overflowing with cases for adjuclication. With these probabilities in view, 
Congress prudently incorporated a section in the Mann-Elkins Act providing that, if, at any time, the business before the Commerce Court should be insufficient to require the services of all the judges, the Chief Justice of the United States may temporarily assign any of the judges to any Circuit Court or Circuit Court of Appeals as he considers practicable.

Exclusive jurisdiction conferred upon this court shall be the same as possessed by the Circuit Courts of the United States over the following kinds of cases:

I. All cases for the enforcement of any order of the Interstate Commerce Commission other than for the payment of money, where enforcement does not involve the collection of a forfeiture or penalty, or the infliction of criminal punishment. This class includes all those cases in which the order of the Interstate Commerce Commission has been disobeyed by the carrier and suit is brought for its enforcement. If orders, other than those excepted, are disobeyed, the Interstate Commerce Commission, or any party injured, or the United States, may apply by filing a petition to the Commerce Court, which court shall enforce obedience by a writ of injunction,or other process, if it determines that the order was regular and properly served. No change is made for the collection of damages, which procedure remains as in the Hepburn Act, requiring the complainant to file his petition in the Circuit Court of the United States and the case proceeds under the general rules of all civil cases, except that the amended Act includes permission to file such suits in state courts of general jurisdiction.

2. Cases brought to enjoin, set aside, annul, or suspencl, in whole or in part, any order of the Interstate Commerce Commission which includes orders of the Commission which the carrier seeks to enjoin or annul. Such suits must be brought against the United States and not against the Interstate Commerce Commission. An appeal of the carrier does not operate as an arrest of the order, but the operation of the order may be suspended, in whole or in part, pending the final hearing and determination of the suit. No order or injumction so restraining or suspending an order of the Interstate Commerce Commission shall be made by the Commerce Court otherwise than upon notice and after hearing, except that in cases where irreparable damage wotild otherwise ensue to the petitioner, the court, or a judge thereof may, on hearing and after three day's notice to the Inter- 
state Commerce Conmission and the Attorney General, allow a temporary stay or suspension, in whole or in part, of the order for not more than sixty days, and the order granting the stay shall contain a specific finding based on evidence submitted that such irreparable damage would result, specifying the nature of claniage. The court may at the time of hearing such application upon a like finding continue the temporary stay or injunction in whole or in part, until its determination upon the application.

An appeal may be taken to the Supreme Court of the United States from an interlocutory order, or decree of the Commerce Court, granting, or continuing, an injunction restraining the enforcement of the order of the Commission, if made within thirty days. Also appeals from the final judgment, or clecrec, of the Commerce Court may be reviewed by the Supreme Court if made within sixty days. Such appeals will in no case operate to supercede, or stay, the judgment unless the Supreme Court shall so direct, and all appeals shall have priority in hearing and determination over all other causes except criminal causes.

3. Certain cases brought under the Elkins Act to enjoin illegal discrimination or departure from the published rate schedules and other unlawful practices by carriers.

4. All suits brought praying for the issuance of a writ of mandanus authorized by section 20 of the Interstate Commerce Act to compel carriers to file proper annual and monthly reports, prescribing the manner of keeping accounts in a uniform system and compelling the movement of interstate traffic, or the furnishing of transportation facilities. These sections also set forth the method how the jurisdiction of the Commerce Court may be invoked. Section 4 of the Commerce Court Act provides that all cases and proceedings relating to the orders of the Interstate Commerce Commission shall be brought by or against the United States and the United States may intervene in any case or proceeding, though not made a party, when the public interests are involved. Section 5 gives the Attorney General control of the Government interest in all cases and proceedings in the Commerce Court, and upon appeal in the Supreme Court of the United States. The Interstate Commerce Commission and parties in interest may intervene, in suits or proceedings and be represented by counsel, and may prosecute, defend, or continue, the suit, or proceeding unaffected by the action or inaction of the Attorney General. 
In all cases within its jurisdiction the Commerce Court and each of the judges assigned thereto shall have and exercise any and all of the powers of a circuit court of the United States so far as the same may be appropriate to the effectual exercise of the jurisdiction conferred. It may issue all writs and process and may, from time to time, establish stch rules and regulations concerning pleading, practice, or procedure and method of taking eviclence in cases or matter within its juriscliction, except as provicled, the practice ancl procedure shall conform as nearly as possible to that in like cases in a circuit court of the Uniterl States.

The juriscliction of the Commerce Court shall be invoked by filing in the office of the clerk of the Court a written petition setting forth briefly and succinctly the facts constituting the petitioner's cause of action, and specifying the relief sought. A copy of such petition shall be forthwith served by the marshal or deputy marshal of the Commerce Court or by the proper United States marshal or deputy marshal upon every clefendant therein named, and when the United States is a party clefendant the service shall be macle by filing a copy of said petition in the office of the Secretary of the Interstate Commerce Commission and in the Department of Justice. Within thirty days after the petition is served, unless that time is extended by order of the court or a judge thereof, an answer to the petition shall be filed in the Clerk's Office and a copy thereof mailed to the petitioner's attorney, which answer shall bricfly and categorically respond to the allegations of the petition. No replication need be filed to the answer, and objections to the sufficiency of the petition or answer as not setting forth a cause of action or clefence must be taken at the final hearing or by motion to dismiss the petition based on said grouncls. which motion may be made at any time before answer is filed. In case no answer shall be filed as provicled herein, the petitioner may apply to the Court on notice for such relief as may be proper upon the facts alleged in the petition. If any pending case or proceeding shall have gone to final judgment or decree in a circuit court of the United States before the opening of the Commerce Court, appeal may be taken from such final jutgment or decree in like manner and with like effect as is now provided by law. Any such case or proceeding within the jurisdiction of the Commerce Court which may have begun in any other court as allowed before the said date shall be forthwith transferred to the Commerce Court. if it has not yet proceeded to final julgment or decree in such 
other court unless it has been finally submitted for the decision of such Court, in which case the cause shall proceed in such Court to final judgment or decree and further proceeding thereafter, and appeal may be taken direct to the Supreme Court, and if remanded such cause may be sent back to the court from which the appeal was taken or to the Commerce Court for further proceeding as the Supreme Court shall direct; and all previous proceedings in such transferred case shall stand and operate notwithstanding the transfer, subject to the same control over them by the Commerce Court and to the same right of subsequent action as if the transferred case or proceeding had been originally begun in the Commerce Court.

The bill in original form aimed at the bringing of suits against the United States rather than against the Interstate Commerce Commission, and provicled that the Attorney General of the United States should have entire and absolute control of all cases in the Commerce Court and in the Supreme Court on appeal, thereby preventing the Interstate Commerce Commission and its attorneys taking any part in litigation. This clause was arranged by the Attorney General so as to clearly clefine the functions of the conflicting clepartments, inasmuch as he was apprehensive that the territory of his department was invacled by the attorneys of the Interstate Commerce Commission, and also that considerable criticism was provoked that the Commission assumed the functions of investigator, judge, and prosecutor. Suits brought to set aside or review its orders were brought co nomine of the Commission and it defended its orders by its own attorneys under a meager supervision of the Attorney General.

The Interstate Commerce Commission is classed as an administrative bodly having powers analogous to a referee and semijudicial. It investigates and issues orders in a judicial manner and in instances frequently has acted as litigant in court in the rlefense of its orders. This arrangement for the exclusion of the Commission brought forth a vigorous protest and the shippers and commercial interests in the Senate administered a stinging blow to the program of the Attorney General. They contended that after careful investigation by the Commission and a favorable decision obtained from that body, which was familiar with the details of the investigation and prosecution in its carlier stages, it was believed that the interest of the public would be better subserved by allowing this Commission or any party, corporation, 
association, or individual in interest to the proceeding to appear as interveners and be represented by counsel before the Commerce Court. The demand of this particular program of the Attorney General, arranged to place all confidence and reliance upon his self-interest, thereby seeking to control and manipulate the entire proceedings in litigation with the aid of some special counsel lacking a thorough knowlectge of technical and complicated traffic questions, in sharp contest with competent and specialized railroad attorneys, was not regarded favorably, inasmuch as the result of such litigation would be positive disaster predetermined.

The Commerce Court consists of five judges appointed by the President. At the beginning the President appointed five additional circuit judges to serve on the Commerce Court for terms of from one to five years. When the respective terms of assignment have expired the Chief Justice of the United States shall designate and assign circuit judges to fill such vacancies for a period of five years. After I9I 5 no circuit judge shall be reassigned to serve in the Commerce Court until an interval of at least one year. The first judge designated shall be the presiding judge of the Court. The salary is the same as that of the circuit judges with an expense allowance of \$1500 per annum. Four judges constitute a quorum and a majority shall concur in all decisions.

For presiding judge the President has appointed Hon. Martin A. Knapp, (late Chairman of the Interstate Commerce Commission), to serve five years; Judge Knapp was born in New York, November 6, 1843 ; admitted to the bar in I869; appointed Interstate Commerce Commissioner by President Cleveland in February, I897; reappointed by President Roosevelt in Decernber, I902 and 1908. He has served as Chairman of the Commission since 1898. Appointed judge of the Commerce Court, December I2, 1910.

Judge Robert W. Archbald, appointed to serve four years, was born in Pennsylvania, September, 1848; graduated from Yale University in $187 \mathrm{I}$; studied law at Scranton, Pa. ; Presiding Judge I888-190I of the 45th judicial district of Pennsylvania, resigned; United States judge, Middle District of Pennsylvania since Igor; declined appointment as a circuit judge in I909. He is a member of several fraternities and societies. Appointed a Commerce Court Judge December I2, I9IO. 
Judge William $H$. Hunt, selected to serve three years, was born at New Orleans, November 5, 1857; entered class of 1878, Yale University, but ill health prevented graduation, (hon. A.M. Yale) ; Attorney General of Montana 1885-7; District judge 1889-94: Governor of Porto Rico Igor-4; United States district judge of Montana I904-10. Appointed judge of the Customs Court in January, 1910. Appointed judge of the Commerce Court in roro.

Judge John E. Carland, selected to serve two years in the Commerce Court, was born December, 1853. Admitted to the bar in 1875; appointed United States Attorney for Dak. Ter. I888; United States District Judge of South Dakota since August 13, 1896 .

Hon. Julian W. Mack, selected to serve one year on the Commerce Court, was born in San Francisco, July I9, I866. Graduated from Harvard Law School in 1887. Admitted to the bar in I890. Professor of Law at the University of Chicago since 1902. Judge of the Circuit Court of Cooks County, Ill., Ist IIl. District, I909. Member of numerous Hebrew societies and other clubs.

Expert knowledge of railroad affairs should be a qualification for an efficient judge of the Commerce Court in the adjudication of the gigantic problems that confront the court. The selection of Judge Knapp as presiding judge should prove beneficial for the interests and protection of the shippers and the railroads. His comprehensive knowledge of transportation affairs, long service on the Interstate Commerce Commission and undeniable ability made him the logical person for this important position, and doubtless was the reason that the President selected him. $\mathrm{He}$ should be acceptable to all parties in interest on account of his broad views and the confidence the people have in him. The general legal knowledge and experience of the other judges will be most valuable to make this court a superior court for the particular class of cases it is established to adjudicate. Judges for this court appointed for a continious service would be admirable but Congress thought otherwise and provision was made that when their terms expired other judges should have an opportunity to display their ability on the Commerce Court.

Some of the most important cases awaiting action are suits for the discrimination for the delivery of oil, discrimination in the distribution of coal cars, discrimination of transit privileges, discrimination in the application of carload rates, unreasonable- 
ness of the Commission's order prescribing coal rates, the validity of the order denying reparation, jurisdiction of the Commission over state rates applicable to interstate conmerce, jurisdiction of the Conmission over electric street car lines. The decisions of these cases are awaited with interest, especially by the railroad companies. All carriers must now have an agent in the city of Washington upon whom all notices and processes may be served for and on behalf of carriers in any suit, or proceeding, pending before the Interstate Commerce Commission and the Commerce Court. All the litigations which heretofore were conducted in the various circuits will be contested in Washington unless otherwise ordered. All decisions of the Commerce Court will eliminate conflicting opinions. All suits mtist be brought for or against the United States. There is, also, a possibility that the Commerce Court will in the near future have jurisdiction over State Railroal Commissions, in which event the business before the court will be greatly increased and the sessions continious. The court is established and portends good results and the people place reliance upon its judges for equality and expedition of suits.

Lewisburg, $P a$.

J. Nezuton Baker. 